\title{
Screening of Ethanolic extract of Diospyros malabarica Desr. Bark for Anti-diabetic and Antioxidant Potential
}

\author{
Satish Annayya Kavatagimath ${ }^{1}$ and Sunil Satyappa Jalalpure ${ }^{2^{*}}$ \\ ${ }^{1}$ Department of Pharmaceutical Biotechnology, K.L.E. University, College of Pharmacy, Nehru nagar, Belagavi-10, Karnataka, India. \\ ${ }^{2}$ K.L.E.U College of Pharmacy and Dr. Prabhakar Kore Basic Science Research Center [BSRC], KLE University, Nehru nagar, \\ Belagavi-590010, Karnataka, India.
}

\begin{abstract}
Objective: Evaluation of ethanolic extract of Diospyrous malabarica Desr. Bark for anti-diabetic and antioxidant potentials. Materials and Methods: Diospyros malabarica Desr. bark ethanol extract was studied for the OGTT study and acute and sub-acute effects on alloxan induced diabetic rats. Blood glucose levels, Serum lipid profiles and histopathological study of pancreas were performed. The Bark extract was also studied for DPPH radical scavenging potential. Results: Ethanolic extract of bark of Diospyros malabarica significantly improved the glucose tolerance test upto $4 \mathrm{~h}$., approximately, $17 \%$ and $29 \%$ reduction in blood glucose level was observed at $2 \mathrm{~h}$ and $4 \mathrm{~h}$ respectively. Blood glucose lowering potential percentage was $19 \%$ at $6 \mathrm{~h}$ in acute studyand after 15 days of treatment it was $39 \%$ in Sub acute study. The extract also showed better activity in quenching DPPH radical. Conclusion: Ethanolic extract $(200 \mathrm{mg} / \mathrm{kg})$ treated diabetic rats showed partial restoration of normal cellular population and size of islet cells.
\end{abstract}

Key words: Alloxan induced diabetic rats, Antioxidant, Antidiabetic, Diospyros malabarica Desr., Hypoglycemic.

\section{INTRODUCTION}

Diabetes mellitus (DM) currently is a major health problem for the people of the world and is a chronic metabolic disorder resulting from a variable interaction of hereditary and environmental factors and is characterized by abnormal insulin secretion or insulin receptor or post receptor events causing glycosuria, hyperglycemia and a disturbance in carbohydrate, fat and protein metabolism and water and electrolyte balance in addition to damaging effect on liver, kidney and $\beta$ cells of pancreas. ${ }^{1,2}$

The number of people suffering from the disease worldwide is increasing at an alarming rate with a projected 366 million peoples likely to be diabetic by the year 2030 as against 191 million estimated in 2000. From literature review it has been revealed that $15-20 \%$ of diabetic patients are suffering from insulin-dependent diabetes mellitus (IDDM) or type-I. ${ }^{1}$
Free radicals have been implicated in the causation of several diseases such as liver cirrhosis, atherosclerosis, cancer, diabetes etc. and compounds that can scavenge free radicals have great potential in ameliorating these disease processes. Antioxidants thus play an important role to protect the human body against damage by reactive oxygen species. Increased oxidative stress has been postulated in the diabetic state. ${ }^{3}$ Antioxidants have been shown to reduce the risk of diabetes onset, improve glucose disposal and improve some of the associated complications. ${ }^{4}$

Many synthetic antioxidants such as butylated hydroxyanisole (BHA), butylated hydroxytoluene (BHT) and propyl gallate (PG) have been used to retard the oxidation process; however, the use of synthetic antioxidants must be under strict regulation due to potential health hazards. ${ }^{5}$ The search for
Submission : 15-05-2015

Revision : :11-06-2015

Accepted : :26-06-2015

DOI: 10.5530/ijper.50.1.22 Correspondence Address Dr. Sunil Satyappa Jalalpure

Professor K.L.E.U College of Pharmacy and Deputy Director, Dr. Prabhakar Kore Basic Science Research Center, K.L.E. University, Nehru Nagar Belagavi-10, Karnataka, India. E-mail:jalalpuresunil@ rediffmail.com

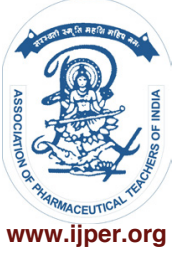




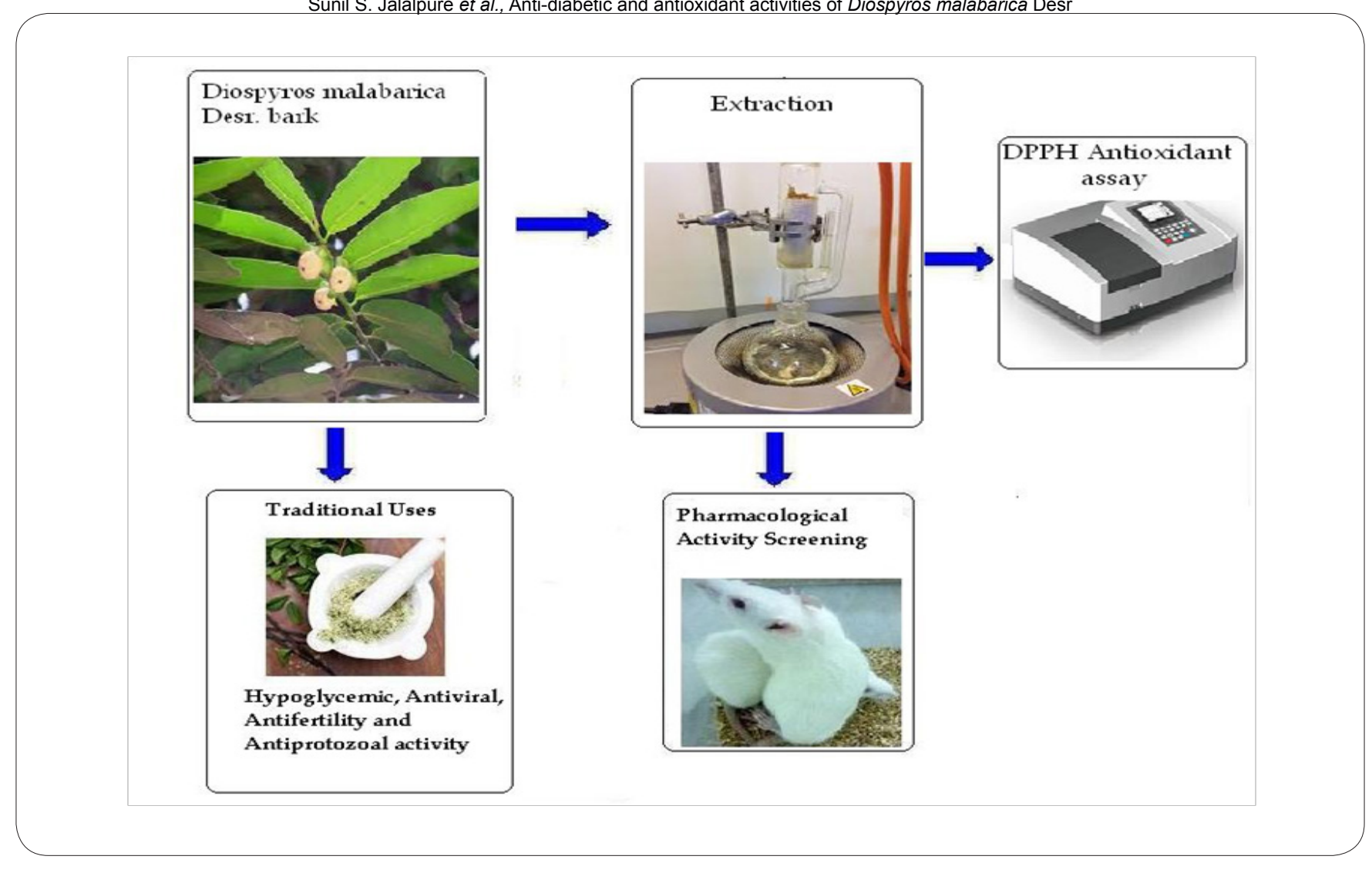

\section{Graphical Abstract}

natural antioxidants as alternatives is therefore of great interest among researchers. The consumption of a diet rich in fresh fruits and vegetables has been associated with a number of health benefits including the prevention of chronic diseases. This beneficial effect is believed to be due, at least partially, to the action of antioxidant compounds, which reduce oxidative damage in the body. ${ }^{5}$

Many plant species have been utilized as traditional medicines but it is necessary to establish the scientific basis for the therapeutic actions of traditional plant medicines as these may serve as the source for the development of more effective drugs.

Diospyros malabarica Kostel belonging to the family Ebenaceae is a medium size evergreen plant found in India. It is popular as Gab or Tinduk. Different phytochemicals have been isolated from leaf and bark which include $\beta$-sitosterol, betulin, betulinic acid, oleanolic acid, lupeol and gallic acid. The plant is traditionally used for the treatment of dysentery and menstrual problems. The plant is also used in snake bite and it possesses antifertility activity. Its fruit juice is useful in the treatment of wound and ulcer, stem bark is useful in intermittent fever. The bark also possesses hypoglycemic, antiviral and antiprotozoal activity. ${ }^{6}$

The literature screened in the process of the proposed work indicates that the selected plant contain classes of chemical constituents which have shown antidiabetic and antioxidant activities. A literature survey revealed that Diospyros malabarica bark ethanol extract has no scientific claims for anti-diabetic and antioxidant activity. Phytochemical and pharmacological investigations of this plant may yield useful information and material for better management for preventing the production of the free radicals and diabetes.

\section{MATERIALS AND METHODS}

\section{Animals}

Healthy adult male Wistar albino rats weighing between 170-200 gm were used for the antidiabetic studies, whereas Swiss albino mice of either sex (20-25 g weight) were used for determination of acute toxicity study. The animals were divided into groups comprising of six animals in each group, with free access to commercial rat pallet diet and water ad libitum. The animal room was maintained at $(25 \pm 2)^{\circ} \mathrm{C}$ with timed lighting on from 6 am to $6 \mathrm{pm}$ and relative air humidity of 30 to $60 \%$. The Institutional Animal Ethics Committee (Vide: JNMC/IAEC/Res$2 / 9 / 2008$ dated $19^{\text {th }}$ December 2008) approved the study.

\section{Chemicals}

All chemicals and solvents used were of analytical grade. Glibenclamide was obtained from Hoechst India. 


\section{Collection of Plant material}

The barks of Diospyros malabarica were collected from surrounding areas of Belagavi districts, Karnataka, India. The specimen was authenticated from Prof. R. S. Goudar, Dept. of Botany, KLES's R. L. Science Institute, Belagavi, Dist. Belagavi, Karnataka India. The herbarium is prepared and stored at Department of Pharmacognosy, K.L.E.S’s College of Pharmacy, Belagavi, Karnataka, India.

\section{Preparation of plant extract}

Barks of Diospyros malabarica was shade dried at room temperature. After complete drying these were subjected to size reduction in a grinder and then sieved through sieve no.40 to get a fine powder, separately. This facilitates the extraction process more effective. These powders of all the four different plants are stored in well-closed glass jars and labeled accordingly.

For extraction of these plant parts cold maceration method and continuous hot extraction (Soxhlet apparatus, 95\% ethanol and petroleum ether (40-60\%) were used. All the extracts were concentrated under reduced pressure at $40^{\circ} \mathrm{C}$ to yield a syrupy mass and stored in amber colored glass jar in refrigerator at $2-8^{\circ} \mathrm{C}$ for further investigations and evaluations.

\section{Preliminary phytochemical investigations}

Preliminary phytochemical investigation revealed the presence of alkaloids, glycosides, tannins, polyphenols, flavonoids and terpenoids in ethanolic extract of Diospyros malabarica bark. The presence of these preliminary phytochemical investigations was also supported by a work. ${ }^{7}$

\section{Experimental design}

Screening of Diospyros malabarica bark ethanol extract for anti-diabetic action was done in rats by conducting glucose tolerance test (GTT) study andevaluating their effects (Single dose and Multidose treatment study) on blood glucose level, Serum lipid profiles and histopathology of pancreas in alloxan diabetic rats.

\section{Acute toxicity study}

Determination of $\mathrm{LD}_{50}$ for extracts is done by OECD guidelines for fixing the dose for biological evaluation. The animals were fasted overnight prior to the experiment and maintained under standard conditions. The $\mathrm{LD}_{50}$ of the extract as per OECD guidelines 423 falls under $5 \mathrm{mg}$, $50 \mathrm{mg}, 300 \mathrm{mg}$ and $2000 \mathrm{mg} / \mathrm{kg}$ b.w. with no signs of acute toxicity at respective doses. The biological evaluation of extract is carried out at $1 / 10$ doses of $\mathrm{LD}_{50}{ }^{8}$

\section{Oral glucose tolerance test (OGTT) ${ }^{9}$}

Fasting blood glucose level of each rat was determined at zero time after overnight fasting with free access to water. Rats were divided into three groups containing six rats each. The first group of animals received $1 \mathrm{ml}$ of $1 \%$ gum acacia suspension orally (Control animals). Remaining groups received Glibenclamide $(2.5 \mathrm{mg} / \mathrm{kg}$ Standard) and Diospyros malabarica bark ethanol extract (200 mg/kg),by oral route using an orogastric tube respectively. Glucose $(2 \mathrm{gm} / \mathrm{kg})$ was orally administered $30 \mathrm{~min}$. after the administration of extract or Glibenclamide or gum acacia suspension. Blood samples were collected from the tail vein under ether anesthesia just prior to and 30, 60, 120 and $240 \mathrm{~min}$ after glucose loading. Glucose levels were estimated using glucoseoxidase-peroxidase reactive strips and a glucometer (Sugar-check, Wockhardt Ltd, Mumbai, India).

\section{Effect of Diospyros malabarica bark ethanol extract on blood glucose levels in alloxan induced diabetic rats [Single dose (Acute) treatment] ${ }^{10}$}

A single intraperitoneal injection of $120 \mathrm{mg} / \mathrm{kg}$ of alloxan monohydrate was employed to induce diabetes in overnight fasted male Wistar albino rats weighing 170$200 \mathrm{gm}$. After $72 \mathrm{hr}$, animals with blood glucose levels higher than $250 \mathrm{mg} / \mathrm{dl}$ were considered diabetic and were included in the study. Animals were divided into four groups including six rats each. Group I: Normal control rats administered $1 \mathrm{ml}$ of $1 \%$ gum acacia suspension; Group II: Diabetic control rats administered $1 \mathrm{ml}$ of $1 \%$ gum acacia suspension; Group III: Diabetic rats administered Glibenclamide $(2.5 \mathrm{mg} / \mathrm{kg}$ ) and Group IV:Diabetic rats administered Diospyros malabarica bark ethanol extract (200 mg/kg) orally. Blood samples were collected from the tail vein prior to and at $30 \mathrm{~min}, 60 \mathrm{~min}, 2$, 4, and $6 \mathrm{~h}$ intervals after the administration of the extract and blood glucose levels were estimated using glucometer.

\section{Effect of Diospyros malabarica bark ethanol extract on blood glucose levels and serum lipid profiles in alloxan induced diabetic rats [Multi dose (sub acute) treatment $]^{10}$}

Diabetes was induced in overnight fasted adult male Wistar albino rats weighing $170-200 \mathrm{gm}$ by a single intraperitoneal injection of $120 \mathrm{mg} / \mathrm{kg}$ of alloxan monohydrate. After $72 \mathrm{hr}$, animals with blood glucose levels higher than $250 \mathrm{mg} / \mathrm{dl}$ were considered diabetic and were included in the study. Animals were divided into four groups including six rats each. Group I: Normal control rats administered $1 \mathrm{ml}$ of $1 \%$ gum acacia suspension; Group II: Diabetic control rats administered $1 \mathrm{ml}$ of $1 \%$ gum acacia suspension; Group III: Diabetic rats administered Glibenclamide $(2.5 \mathrm{mg} / \mathrm{kg})$ 


\begin{tabular}{|c|c|c|c|c|c|c|}
\hline Exp. Group & \multirow{2}{*}{ Treatment } & \multicolumn{5}{|c|}{ Blood glucose concentration (mg/dl) (mean \pm S.E.M.) } \\
\hline$(n=6)$ & & In fasting & $30 \mathrm{~min}$ & $60 \mathrm{~min}$ & $120 \mathrm{~min}$ & $240 \mathrm{~min}$ \\
\hline \multirow[t]{2}{*}{ I } & Normal control & \multirow{2}{*}{$92.8 \pm 2.9$} & \multirow{2}{*}{$161.6 \pm 4.1$} & \multirow{2}{*}{$162.7 \pm 2.6$} & \multirow{2}{*}{$161.2 \pm 3.5$} & \multirow{2}{*}{$132.6 \pm 3.2$} \\
\hline & (1\% gum acacia) & & & & & \\
\hline II & $\begin{array}{c}\text { Glibenclamide (2.5 } \\
\mathrm{mg} / \mathrm{kg})\end{array}$ & $96.0 \pm 2.4$ & $143.0 \pm 2.4^{*}$ & $145.8 \pm 1.2^{*}$ & $137.0 \pm 2.2^{*}$ & $98.9 \pm 1.2^{*}$ \\
\hline III & $\begin{array}{c}\text { Diospyros malabarica } \\
\text { bark ethanol extract } \\
(200 \mathrm{mg} / \mathrm{kg})\end{array}$ & $92.0 \pm 5.2$ & $136.0 \pm 3.2^{*}$ & $134.5 \pm 2.3^{*}$ & $133.0 \pm 4.2^{*}$ & $94.03 \pm 2.5^{*}$ \\
\hline
\end{tabular}

Significantly different from control: ${ }^{*} P<0.05 ; n=$ no of animals in each group

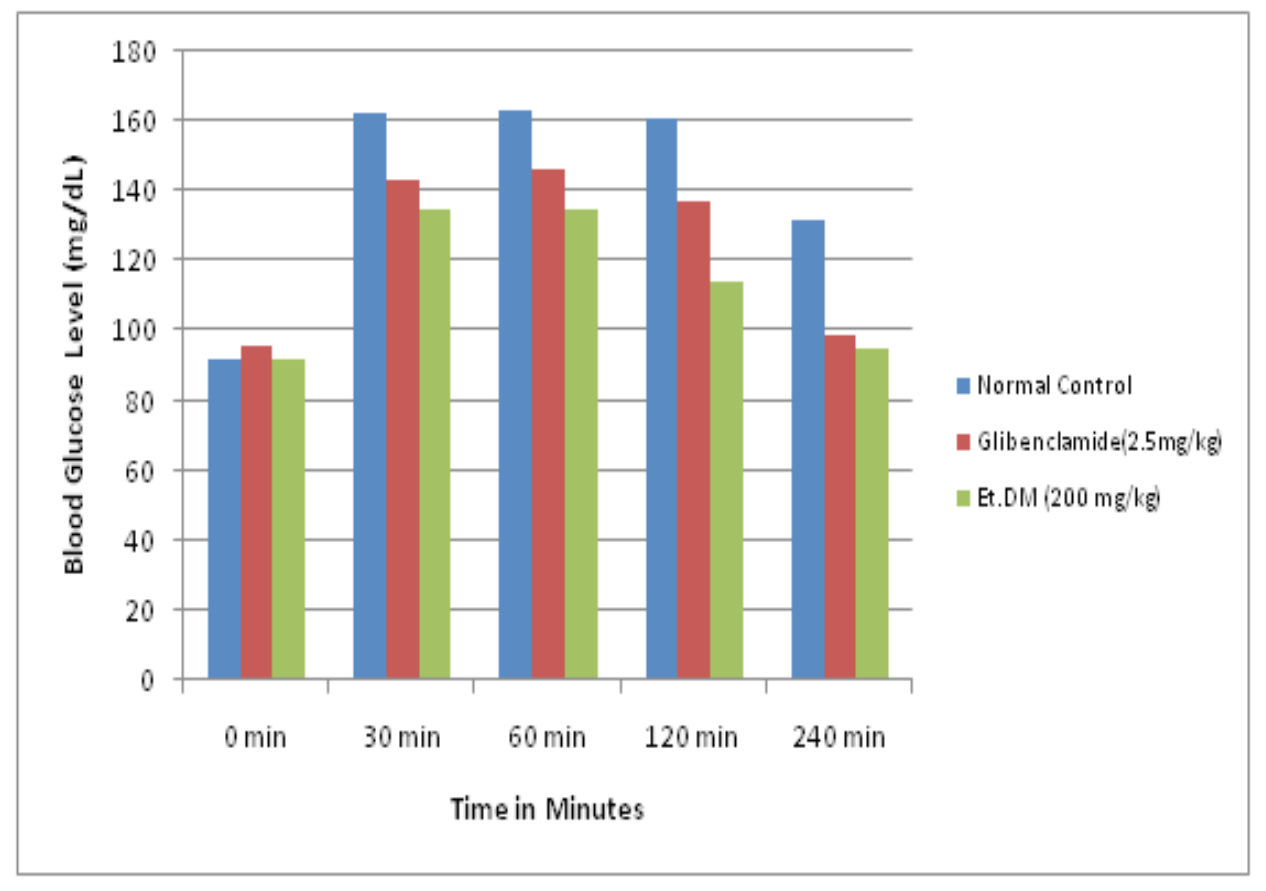

Figure 1: Effect of Diospyros malabarica bark ethanol extract on the blood glucose concentration in glucose loaded rats

and Group IV: Diabetic rats administered Diospyros malabarica bark ethanol extract $(200 \mathrm{mg} / \mathrm{kg})$ orally. These rats were given the same doses of the extract once daily for 15 days in this study. Blood samples were collected from the tail vein of nonfasted rats on days $0,5,10$ and 15 of extract administration and blood glucose levels were estimated using glucometer. Serum lipid profiles on day 15 were measured by an autoanalyzer.

\section{Histopathological studies ${ }^{11}$}

Pancreatic tissues from rats of all groups of Multi dose (Sub acute) treatment were subjected to histopathological studies. The whole pancreas from each animal was removed after sacrificing the animal under anesthesia and was collected in 10\% formalin solution and immediately processed by the paraffin technique. Sections of
$5 \mu \mathrm{m}$ thickness were cut and stained by hematoxylin and eosin ( $\mathrm{H}$ and $\mathrm{E})$ for histological examination.

\section{In vitro Antioxidant-DPPH free radical scavenging activity $^{12}$}

The free radical scavenging activity of Diospyros malabarica bark ethanol extract was measured by 1,1-diphenyl2-picryl-hydrazyl (DPPH). For DPPH assay, the method of Blois was adopted. The capacity of Diospyros malabarica bark ethanol solvent extract to scavenge the lipid-soluble DPPH radical was monitored at an absorbance of $517 \mathrm{~nm}$. Ethanol bark extract $(1 \mathrm{ml})$ of Diospyros malabarica, at different concentration was allowed to react with DPPH. Thirty minutes later, the absorbance was measured at $517 \mathrm{~nm}$. The percentage inhibition of absorbance was calculated for each concentration relative to a blank absorbance using the spectrophotometer. The 


\begin{tabular}{|c|c|c|c|c|c|c|}
\hline \multicolumn{7}{|c|}{ Table 2: Effect of Diospyros malabarica bark ethanol extract on the blood glucose levels in alloxan-dia- } \\
betic rats (Single dose treatment /acute study)
\end{tabular}

${ }^{*} P<0.05$ Significant, compared to normal, ${ }^{\#} P<0.05 \&{ }^{\# \#} P<0.01$ Significant, compared to diabetic control; $\mathrm{n}=$ no of animals in each group

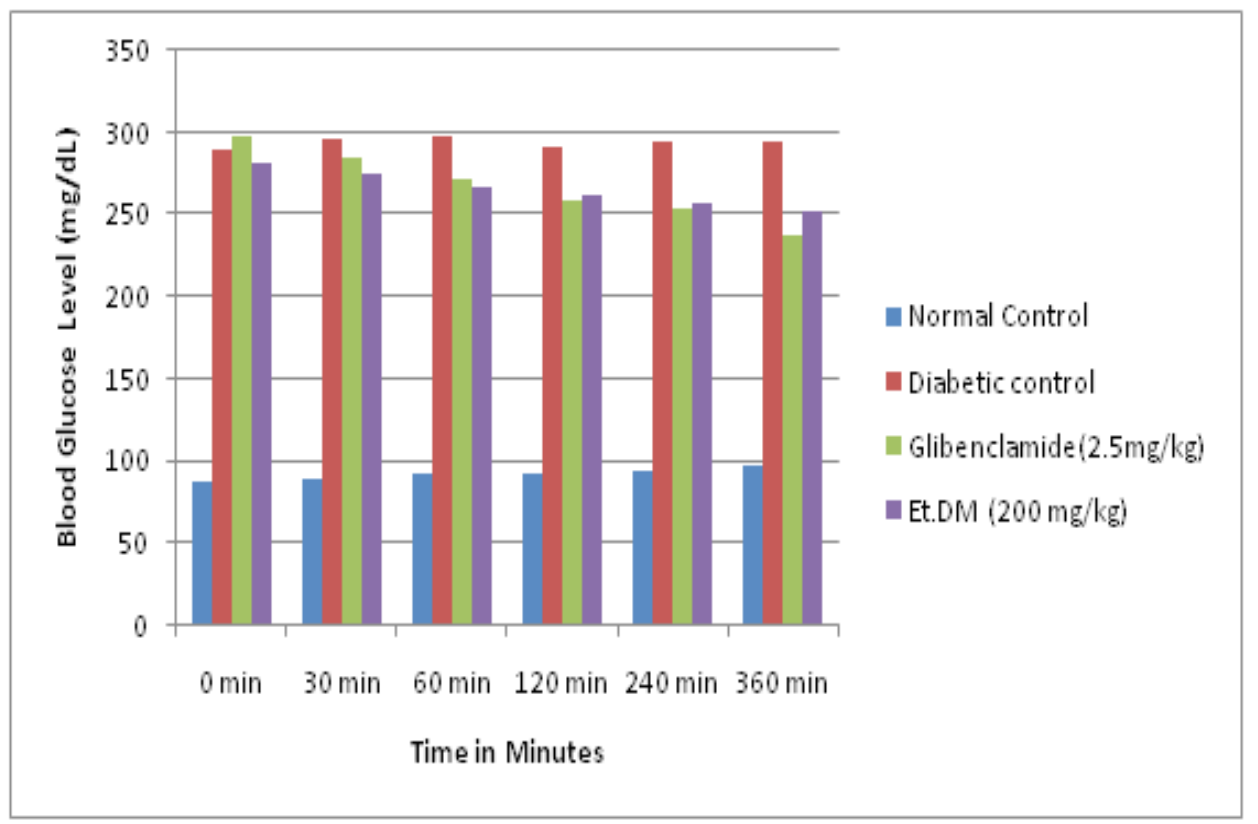

Figure 2: Effect of Diospyros malabarica bark ethanol extract on the blood glucose concentration in alloxan-diabetic rats (Single dose treatment / acute study)

\begin{tabular}{|c|c|c|c|c|c|}
\hline Exp.Group & \multirow{2}{*}{ Treatment } & \multicolumn{4}{|c|}{ Fasting blood glucose concentration (mg/dl) (mean \pm S.E.M.) } \\
\hline$(n=6)$ & & $0^{\text {th }}$ Day & $5^{\text {th }}$ Day & $10^{\text {th }}$ Day & $15^{\text {th }}$ Day \\
\hline \multirow{2}{*}{ I } & Normal control & \multirow{2}{*}{$87.35 \pm 2.2$} & \multirow{2}{*}{$87.75 \pm 2.8^{\# \#}$} & \multirow{2}{*}{$87.35 \pm 2.3^{\#}$} & \multirow{2}{*}{$88.35 \pm 1.8^{\# \#}$} \\
\hline & (1\% gum acacia) & & & & \\
\hline II & $\begin{array}{c}\text { Diabetic control ( } 1 \% \text { gum } \\
\text { acacia) }\end{array}$ & $288.2 \pm 5.2$ & $277.6 \pm 7.1^{* *}$ & $268.3 \pm 4.2^{* *}$ & $256.8 \pm 4.1^{*}$ \\
\hline III & Glibenclamide $(2.5 \mathrm{mg} / \mathrm{kg})$ & $300.3 \pm 6.9$ & $222.3 \pm 12.3^{* * \#}$ & $190.3 \pm 12.8^{* * \#}$ & $172.3 \pm 14.3^{* * \#}$ \\
\hline IV & $\begin{array}{c}\text { Diospyros malabarica } \\
\text { bark ethanol extract (200 } \\
\mathrm{mg} / \mathrm{kg})\end{array}$ & $276.3 \pm 6.7$ & $220.3 \pm 12.5^{\star *}$ & $166.3 \pm 6.5^{* \# \#}$ & $158.3 \pm 6.4^{* * \#}$ \\
\hline
\end{tabular}

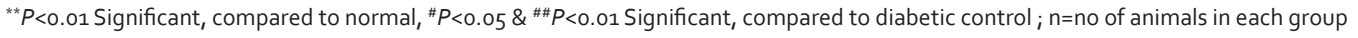




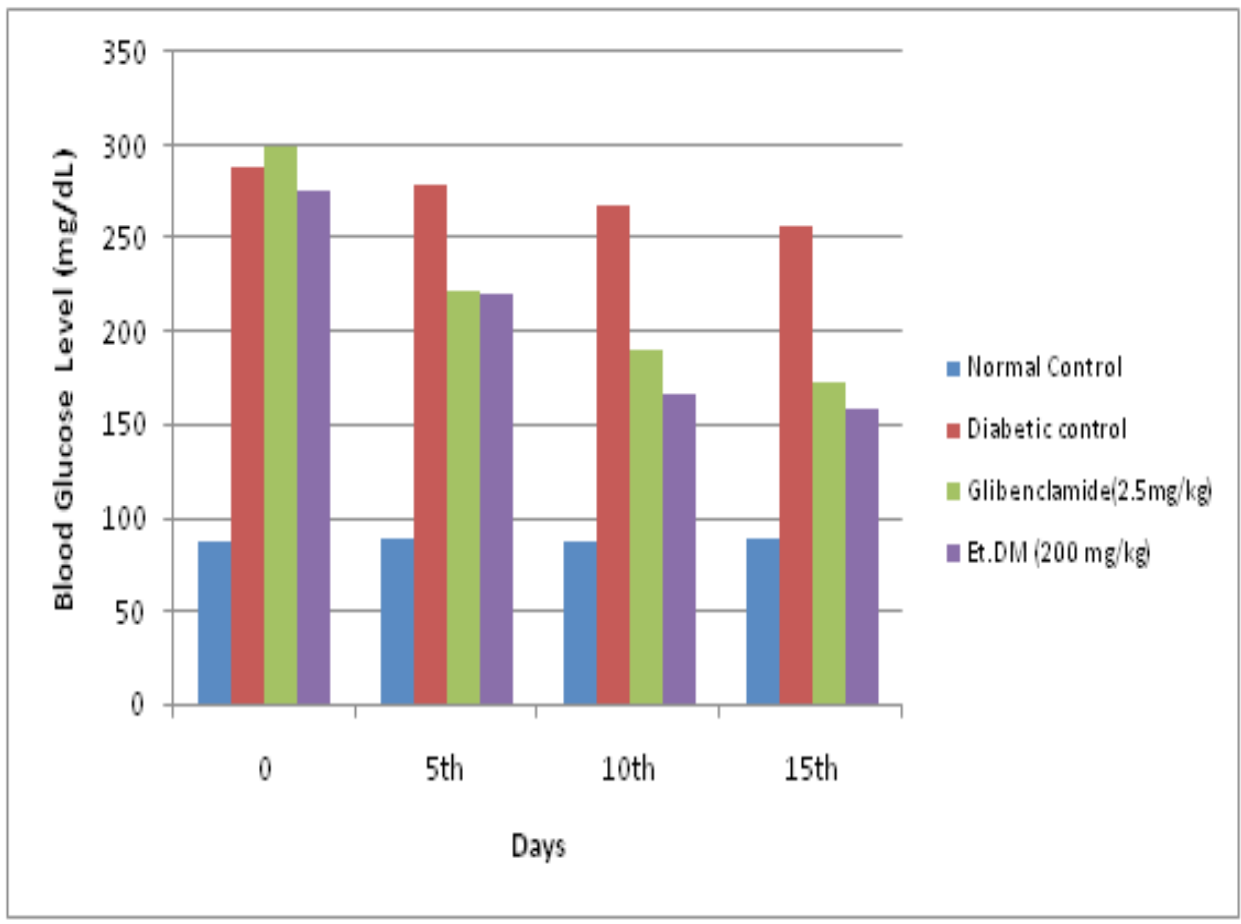

Figure 3: Effect of Diospyros malabarica bark ethanol extract on the blood glucose levels in alloxan-diabetic rats (Multi dose treatment /sub acute study)

\begin{tabular}{|c|c|c|c|c|c|c|}
\hline $\begin{array}{l}\text { Exp. Group } \\
\qquad(n=6)\end{array}$ & Treatment & TGL mg/dl & HDL mg/dl & $\begin{array}{l}\text { VLDL mg/ } \\
\text { dl }\end{array}$ & LDL mg/dl & $\begin{array}{c}\text { Total } \\
\text { Cholesterol } \\
\text { mg/dl }\end{array}$ \\
\hline \multirow[t]{2}{*}{ I } & Normal control & \multirow[t]{2}{*}{$76.83 \pm 2.0$} & \multirow[t]{2}{*}{$50.3 \pm 2.1$} & \multirow[t]{2}{*}{$21 \pm 0.9$} & \multirow[t]{2}{*}{$18 \pm 1.2$} & \multirow[t]{2}{*}{$53.3 \pm 2.5$} \\
\hline & (1\% gum acacia) & & & & & \\
\hline II & Diabetic control & $123 \pm 2.7$ & $35.2 \pm 0.9$ & $38.3 \pm 1.7$ & $39.7 \pm 1.9$ & $88.2 \pm 2.9$ \\
\hline III & $\begin{array}{c}\text { Glibenclamide } \\
(2.5 \mathrm{mg} / \mathrm{kg})\end{array}$ & $87 \pm 2.3$ & $47 \pm 1.8$ & $22.5 \pm 1.2$ & $21.2 \pm 2.2$ & $59.5 \pm 1.7$ \\
\hline IV & $\begin{array}{c}\text { Diospyros } \\
\text { malabarica bark } \\
\text { ethanol extract } \\
(200 \mathrm{mg} / \mathrm{kg})\end{array}$ & $105 \pm 1.8$ & $39.2 \pm 0.7$ & $24.2 \pm 1.3$ & $27.2 \pm 1.3$ & $69 \pm 1.4$ \\
\hline
\end{tabular}

$* P<0.05 \& * * P<0.01$ Significant, compared to diabetic control $; \mathrm{n}=$ no of animals in each group 


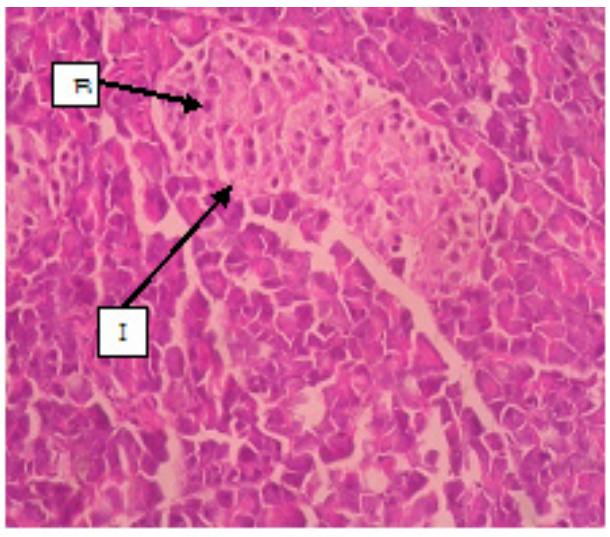

(A)

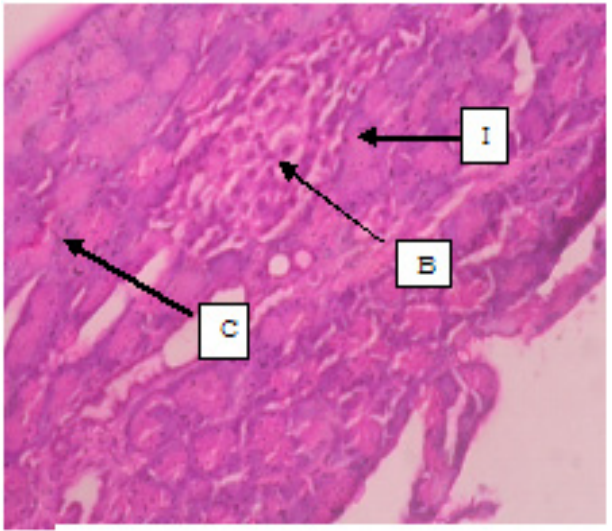

(C)

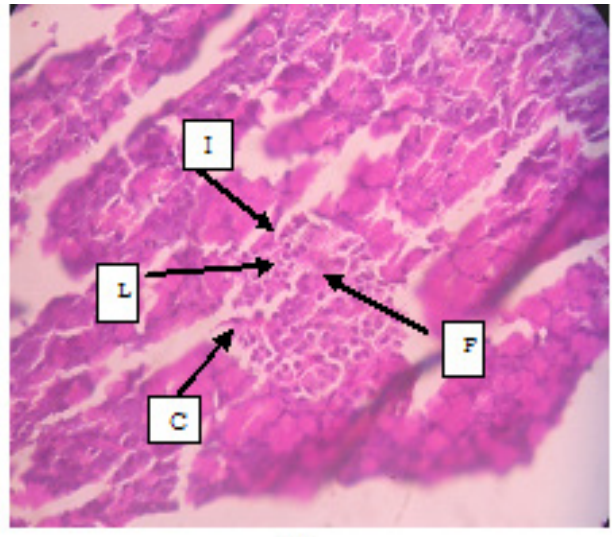

(B)

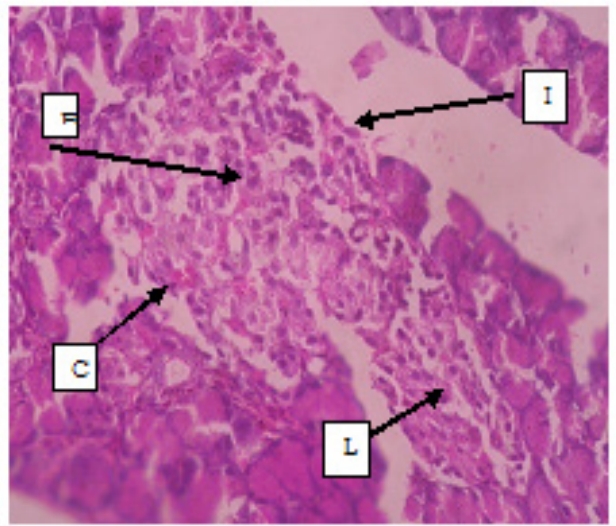

(D)

$\begin{array}{ll}\mathrm{I}=\text { is lets of L angerhans } & \begin{array}{l}\mathrm{C}=\text { congestion } \\ \mathrm{L}=\text { lymphocytes }\end{array} \\ \mathrm{B}=\text { beta cells }\end{array} \quad \mathrm{F}=$ fibrosis

Figure 4: Histological morphology of rat pancreas after 15 days of treatment with ethanol extract of Diospyros malabarica bark. (A) Normal control rats showed normal pancreatic tissue, while (B) Alloxan-induced diabetic rats had severe decrease in number of islets of Langerhans cells and $\beta$ cells. Pancreatic tissue of diabetic rats treated with (C) Glibenclamide $(2.5 \mathrm{mg} / \mathrm{kg})$ and (D) ethanol extract of Diospyros malabarica bark $(200 \mathrm{mg} / \mathrm{kg})$ showed partial restoration of normal cellular population and size of islet cells

\begin{tabular}{|c|c|c|}
\hline \multirow[b]{2}{*}{$\begin{array}{l}\text { Concentration } \\
(\mu \mathrm{g} / \mathrm{ml})\end{array}$} & \multicolumn{2}{|c|}{ DPPH scavenging (\% inhibition) } \\
\hline & $\begin{array}{c}\text { Ethanol extract of } \\
\text { Diospyros malabarica } \\
\text { bark }\end{array}$ & $\begin{array}{c}\text { BHT } \\
\text { (Butylatedhydroxytolune) }\end{array}$ \\
\hline 10 & 2.52 & 20.08 \\
\hline 50 & 14.01 & 38.17 \\
\hline 100 & 19.84 & 59.64 \\
\hline 250 & 37.35 & 90.26 \\
\hline 500 & 54.08 & 97.22 \\
\hline 1000 & 73.35 & 95.23 \\
\hline IC 50 & $462 \mu \mathrm{g} / \mathrm{mL}$ & $419 \mu \mathrm{g} / \mathrm{mL}$ \\
\hline
\end{tabular}

Data represents mean \pm S.E.M. of triplicate analysis 
DPPH scavenging capacity of the extracts is compared with that of BHT (Butylated hydroxytolune). Lower absorbance of the reaction mixture indicates higher free radical scavenging activity. All determinations are carried out at least three times, and in triplicate. $\mathrm{IC}_{50}$ value in the tested compound is, the concentration required to scavenge 50\% DPPH free radical. Percentage inhibition was calculated as DPPH radical scavenging activity.

Where, Abs control is the absorbance of initial conc. of DPPH radical;

Abs sample is the absorbance of DPPH radical + sample Extract /standard

\section{Statistical analysis}

Values are presented as mean \pm S.E.M. Statistical difference between treatments and the controls were tested by one-way analysis of variance (ANOVA), followed by Dunnett's multiple comparison test using the "Stat" statistics computer program. A difference in the mean values of $\mathrm{P}<0.05$ was considered to be statistically significant.

\section{RESULTS}

\section{Acute toxicity study}

Acute toxicity study revealed no mortality or any toxic reactions with oral administration of ethanol extract of bark of Diospyros malabarica even at the highest dose $(2000 \mathrm{mg} / \mathrm{kg})$. The biological evaluation of extract is carried out at $1 / 10$ doses of $\mathrm{LD}_{50}{ }^{8}$

\section{Oral glucose tolerance test (OGTT)}

Ethanol extract of bark of Diospyros malabarica significantly $(\mathrm{P}<0.05)$ improved the glucose tolerance test up to $4 \mathrm{~h}$ (Table 1 and Figure 1). Approximately, 17 and 29\% reduction in blood glucose level was observed in control values at the $2 \mathrm{~h}$ and $4 \mathrm{~h}$ respectively. The Glibenclamide also improved the glucose tolerance test up to $4 \mathrm{~h}$.

\section{Effect of Diospyros malabarica bark ethanol extract on blood glucose levels in alloxan induced diabetic rats [Single dose (Acute) treatment]}

An administration of Diospyros malabarica bark ethanol extract was found to reduce blood glucose level in alloxan induced diabetic rats in single dose study. Diospyros malabarica bark ethanol extract exhibited significant $(\mathrm{P}<0.05)$ antihyperglycemic efficacy from $1 \mathrm{~h}$ after its oral administration, the effect lasted up to $6 \mathrm{~h}$ when compared with normal rats and diabetic control rats. Blood glucose lowering potential percentage of Diospyros malabarica was $14 \%$ at $6 \mathrm{~h}$ after administration, while the standard drug Glibenclamide $(2.5 \mathrm{mg} / \mathrm{kg})$ caused $19 \%$ reduction of blood glucose at the same time interval when compared with diabetic control rats (Table 2 and Figure 2).

\section{Effect of Diospyros malabarica bark ethano lextract on blood glucose in alloxan induced diabetic rats [Multi dose (sub acute) treatment]}

In order to determine the sub acute effects, Diospyros malabarica bark ethanol extract was administered throughout 15 days consecutively. The blood glucose level of each animal was monitored on $0,5^{\text {th }}, 10^{\text {th }}$ and $15^{\text {th }}$ days after the administration of the test samples. As shown in the Table 3 and Figure 3 initial antidiabetic activity was observed on 5 th day and continued to increase in all groups during the experimental period.

During the multi dose treatment period, administration of ethanol extract of bark of Diospyros malabarica (200 $\mathrm{mg} / \mathrm{kg} /$ day) caused a significant decrease of $21 \%$, $38 \%$ and $39 \%$ in blood glucose levels on $5^{\text {th }}, 10^{\text {th }}$ and $15^{\text {th }}$ day intervals, respectively, when compared with diabetic control group.

\section{Effect of Diospyros malabarica bark ethanol extract on serum lipid profiles in alloxan induced diabetic rats [Multi dose (sub acute) treatment]}

Hyperlipidemia is a common complication of alloxaninduced diabetes mellitus in experimental animals. Observations of hypoglycemic effect of ethanol extract of bark of Diospyros malabarica in alloxan-induced hyperlipidemic rats is shown in Table 4. In serum lipid profiles study on day 15 , diabetes which is induced by alloxan lead to a significant changes in levels of Serum cholesterol, triglyceride, LDL, VLDL, and HDL. When compared to control (healthy rats), serum total cholesterol (TC), triglyceride (TG), low density lipoprotein (LDL) and Very low-density lipoprotein (VLDL) increased and high density lipoprotein cholesterol (HDL) decreased clearly in hyperlipidemic rats. After the treatment of ethanol extract of bark of Diospyros malabarica $(200 \mathrm{mg} / \mathrm{kg})$ and Glibenclamide in hyperlipidemic rats for 15 consecutive days, there was a significant decrease in serum lipids (TC, TG, LDL and VLDL), while there was an marked increase in HDL.

\section{Histopathological studies}

Histopathological examination of pancreas of these animals showed (Figure 4) comparable regeneration of Islets of Langerhans and $\beta$ cells by ethanol extracts of Diospyros malabarica bark and Glibenclamide, which were earlier, under necroses by alloxan. Figure 4 (A-D) depicts the islets of the pancreas of rats in different groups. Photomicrographs (A) of the normal healthy control group showed normal acini and normal cellular population of the islets of Langerhans. However, in the alloxan only treated rats, there was extensive damage of 
the islets of Langerhans and they appeared to be irregular (B). Treatment of diabetic rats with glibenclamide showed moderate expansion of cellular population and size of islet cells (C). However, ethanol extract $(200 \mathrm{mg} /$ $\mathrm{kg})$ treated-diabetic rats showed partial restoration of normal cellular population and size of islet cells (D).

\section{In vitro Antioxidant-DPPH free radical scavenging activity}

Several concentrations ranging from 10-1000 $\mu \mathrm{g} / \mathrm{ml}$ of the ethanol extract of bark of Diospyros malabarica tested for their antioxidant activity by DPPH model. It has been observed that free radicals were scavenged by the Diospyros malabarica bark ethanol extract in a concentration dependent manner in this DPPH assay (Table 5). The ethanol extract of bark of Diospyros malabarica showed DPPH radical scavenging activity with an $\mathrm{IC}_{50}$ value of $462 \mu \mathrm{g} / \mathrm{ml}$ when compared with Standard BHT (Butylated hydroxytolune) $\mathrm{IC}_{50}$ value of $419 \mu \mathrm{g} / \mathrm{ml}$.

\section{DISCUSSION}

Blood sugar control is highly important over time for a diabetic patient. As the patient ages, the oral hypoglycemic drugs are not effective in keeping blood sugar levels in normal range, thus creating many complications. Medicinal plants are used in several countries to manage DM and are thought to be less toxic than allopathic hypoglycemic drugs like biguanides, sulphonylureas or insulin therapy.

Oxidative stress has been suggested as a one of the contributory factor in the pathogenesis of diabetes. Diabetes, by itself, increases the production of tissue damaging reactive oxygen species (ROS) by glucose autoxidation and/or no enzymatic protein glycosylation. ${ }^{13}$ Diabetic patients are exposed to oxidative stress and complications of diabetes, seems to be mediated by oxidative stress. Hyperglycemia is one of the main causes of oxidative stress in type 2 diabetes. Under hyperglycemia, the increased blood level of various reducing sugars promotes protein glycation and advanced glycation end products (AGEs). Reactive oxygen species (ROS) are formed in this process, which trigger tissue damage. Recently, the progressive deterioration of $\beta$ cell function in type 2 diabetes has been accounted in the oxidative stress-induced tissue damage. ${ }^{14}$

For investigating the free radical scavenging activities of several natural compounds, the 1,1-diphenyl -2-picryl hydrazyl (DPPH) radical was widely used. Plants constitutes a rich source of antioxidants, which include tocopherols, Vitamin C, phenolic compounds, carotenoids, ${ }^{15}$ flavonoids, terpenoids, anthraquinones, steroids, strychnine and eugenol alkaloids. ${ }^{16}$
In the present study, free radicals were scavenged by the ethanol extract of Diospyros malabarica bark in a concentration dependent manner in the DPPH assay, so it is concluded that the Diospyros malabarica bark ethanol extract has potent in vitro antioxidant potential, which is our primary outcome measure. This antioxidant potential of extract is attributed due to the presence of flavonoids and terpenoids like constituents present therein.

The Overall findings show that ethanol extract of Diospyros malabarica bark possesses marked antihyperglycemic activity which was proved by improvement of glucose tolerance test and by lowering the blood glucose levels in alloxan-induced diabetic rats in single dose (acute) and multi dose (sub acute) treatment studies, which is our secondary outcome measure. The ethanol extract of bark of Diospyros malabarica and Glibenclamide exhibited remarkable blood glucose lowering effect in glucose tolerance test. The hypoglycemic effect of plant extract comparable to Glibenclamide, suggests that the test extracts may act by regenerating the $\beta$ cells in alloxan- $\beta$ induced diabetes. ${ }^{17}$ Alloxan causes diabetes through its ability to destroy the insulin producing $\beta$ cells of the pancreas. In vitro studies have shown that alloxan is selectively toxic to the pancreatic $\beta$ cells, causing cell necrosis. The cytotoxic action of alloxan is mediated by reactive oxygen species, with a simultaneous massive increase in cytosolic calcium concentration, leading to a rapid destruction of $\beta$ cells. ${ }^{18}$

In proposed study, damage of pancreas was observed in alloxan-treated diabetic control rats (Figure 4B). The glibenclamide-treated group showed regeneration of $\beta$ cells (Figure 4C). The comparable regeneration of $\beta$ cells was also shown by ethanol extracts of Diospyros malabarica bark (Figure 4D). Photomicrographs reinforce healing of pancreas by the ethanol extracts of Diospyros malabarica as a plausible mechanism of their antidiabetic activity. The antidiabetic activity of Diospyros malabarica may be due to the presence of flavonoids and terpenoids. It is reported that flavonoids constitute the active biological principles of most medicinal plants with hypoglycemic and antidiabetic properties. ${ }^{19}$ Over 150 plant extracts and some of their active principle including flavonoids, quinones and tannins are known to be used for the treatment of diabetes. ${ }^{20}$ After Diospyros malabarica treatment, blood glucose, TC, TG, LDL and VLDL of all tested rats were significantly decreased and at the same time HDL was increased. This provided evidence in favor of the view that Diospyros malabarica could play an important role in treating diabetic and hyperlipidemic patients. Our study reveals that the plant containing flavonoids and terpenoids phytoconstituents 
are having antixidant and hypoglycemic potential. No exact findings about which phytoconstituent responsible for producing such activity is limitation of this study. However these preclinical data help us to carryout clinical trials to discover promising medicine to treat diabetes and hyper lipidemic disorders in future.

\section{CONCLUSION}

It is conceivable that antioxidant/free radical scavenging activity of Diospyros malabarica bark ethanol extract is one of the mechanism associated with antidiabetic effect. The other mechanism is regeneration and moderate expansion of cellular population and size of islet of Langerhans and $\beta$ cells by ethanol extracts of Diospyros malabarica bark. However, ethanol extract $(200 \mathrm{mg} / \mathrm{kg})$ treated-diabetic rats showed partial restoration of normal cellular population and size of islet cells. These results seem to confirm the alleged antidiabetic activity by the traditional medicine. This antioxidant and antidiabetic potential of extract is attributed due to the presence of flavonoids and terpenoids like constituents present therein.

\section{ACKNOWLEDGMENTS}

The authors are thankful to K.L.E. University College of Pharmacy, Belgaum, India, for providing facilities to carry out this research work. The authors are grateful Prof. R. S. Goudar, Dept. of Botany, KLES's R. L. Science Institute, Belagavi, (Karnataka) India for authenticating the plant material.

\section{SUMMARY}

- Diospyros malabarica Desr. Plant belonging to the family Ebenaceae.

- The ethanolic extract of bark, has shown antioxidant and antidiabetic potentials which was proved by DPPH assay, Oral Glucose Tolerance Test, acute study, sub acute treatment studies and Histopathological study of Pancreas.

- In present study, the comparable regeneration of $\beta$ cells was shown by ethanol extracts of Diospyros malabarica Desr.bark, which is a plausible mechanism of the antidiabetic activity.

- The antidiabetic activity of plant may be due to the presence of flavonoids and terpenoids.

\section{About Authors}

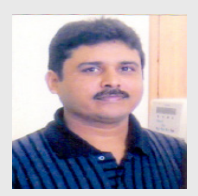

Dr.Sunil Satyappa Jalalpure: Presently working as Professor Department of Pharmacognosy, College of Pharmacy, Belagavi and Deputy Director, Dr. Prabhakar Kore Basic Science Research Center, KLE University, Belagavi, Karnataka. His areas of research interests include isolation/ characterization of active principles from medicinal plants and their pharmacological screening for various biological activities and training the research students in Pharmacognosy, Phytochemistry and Biotechnological aspects with modern tools and techniques. He has published 66 Research Papers and 69 Poster presented in national and international workshops and conferences. 02 nos. of books. He has delivered more than 40 invited talks on various platforms. Forty six

\section{REFERENCES}

1. Mishra A, Garg GP. Antidiabetic activity of fruit pulp of Cordia dichotoma in alloxan induced diabetic rats. Indian Journal of Pharmaceutical Sciences and Research 2011; 2(9): 2314-9.

2. Andallu B, Ramya V. Anti-hyperglycemic, cholesterol-lowering and HDLraising effects of cumin seeds in type 2 diabetes. Journal of Natural Remedies 2007; 7(1): 142-9.

3. Sabu MC, Ramadasan K. Anti-diabetic activity of medicinal plants and its relationship with their antioxidant property. Journal of Ethnopharmacology 2002; 81(2): 155-60.
(46) postgraduates have been successfully guided for the completion of their M.Pharm dissertation and presently guiding nine (09) Ph. D students for their thesis. Five (5) candidates successfully completed Ph.D.

Satish Annayya Kavatagimath: Working as Assistant Professor, Department of Pharmaceutical Biotechnology-K.L.E.University's College of Pharmacy, Belgaum. 12 year of experience in teaching. Under graduate as well as Post Graduate students. He has published 03 scientific research Papers and presented 14 at national conferences. Presently guiding 01 PG Student as a Guide.
4. Letitia MM, Timothy J. Antioxidant activity relates to plant part, life form and growing condition in some diabetes remedies. Journal of Ethnopharmacology 2007; 112(3): 461-9.

5. Sudha G, Sangeetha MP, Indhu RS, Vadivukkarasi S. In vitro free radical scavenging activity of raw pepino fruit (Solanum muricatum aiton). International Journal of Current Pharmaceutical Research 2011; 3(2): 137-40.

6. Mondal SK, Chakraborty G, Gupta M, Mazumder UK. In vitro antioxidant activity of Diospyros malabarica Kostel bark. Indian Journal of Experimental Biology 2006; 44(1): 39-44.

7. Maridass M, Ghanthikumar S, Raju G. Preliminary Phytochemical Analysis of Diospyros Species. Ethnobotanical Leaflets 2008; 12(1): 868-72. 
8. Umamaheswari M, Asokkumar K, Rathidevi R, Sivashanmugam AT, Subhadradevi V, Ravi TK. Anti-ulcer and in vitro antioxidant activities of Jasminum grandiflorum L. Journal of Ethnopharmacology 2007; 110(3): 464-70.

9. Shirwaikar A, Rajendran K, Barik R. Effect of aqueous bark extract of Garuga pinnata Roxb. in streptozotocin-nicotinamide induced type-Il diabetes mellitus. Journal of Ethnopharmacology 2006; 107(2): 285-90.

10. Nilufer O, Mustafa A, Didem DO, Fatma E, Erdem Y. In vivo assessment of antidiabetic and antioxidant activities of grapevine leaves (Vitis vinifera) in diabetic rats. Journal of Ethnopharmacology 2006; 108(2): 280-6.

11. Luna LC. Manual of histological screening methods of Armed Forces Institute of Pathology. Ed 125. New York: Mc Graw Hill Book Co; 1960.

12. Gulcin I, Elias R, Gepdiremen A, Boyer L, Koksal E. A comparative study on the antioxidant activity of fringe tree (Chionanthus virginicus L.) extracts. African Journal of Biotechnology 2007; 6(4): 410-8.

13. Gokee G, Zeki M, Haznedaroglu. Evaluation of antidiabetic, antioxidant and vasoprotective effects of Posidonia oceanica extract. Journal of Ethnopharmacology 2008; 115(1): 122-30.
14. Kimoto K, Kenji S, Tayako K, Yoshiaki H, Hitoshi I, Hidenori K, et al. Gliclazide protects pancreatic b-cells from damage by hydrogen peroxide. Biochemical and Biophysical Research Communications 2003; 303(1): 112-9.

15. Rashmi DR, Subramaniam V. In vitro antioxidant activity of medicinally important Achyranthes aspera- A preliminary study. Indian drugs 2006; 44(2): 128-32.

16. Tripathi YB, Chaurasia S, Tripathi E, Upadhey A, Dubey GP. Bacopa monniera Linn. as an antioxidant: Mechanism of action. Indian Journal of Experimental Biology 1996; 34(6): 523-6.

17. Ghosh S, Suryawanshi SA. Effect of Vinca rosea extracts in treatment of alloxan rats. Indian Journal of Experimental Biology 2001; 39(8): 748-59.

18. Sharma S, Chaturvedi M, Edwin E, Shukla S, Sagrawat H. Evaluation of the phytochemicals and antidiabetic activity of Ficus bengalensis. International Journal of Diabetes in Developing Countries 2007; 27(2): 56-9.

19. Wollenweber LE, Cody V, Middleton EJ, Harborne JB, Beretz A. Plant Flavonoids in biology and medicine II: Biochemical, cellular and medicinal properties. Progress in Clinical and Biology Research 1988; 280: 1-461.

20. Suba V, Murugesan T, Bhaskara Rao R, Ghosh L, Pal M, Subhash C, et al. Antidiabetic potential of Barleria lupulina extract in rats. Phytomed. 2004; 11(2-3): 202-5. 